\title{
Bone remodelling is not affected by consumption of a sodium-rich carbonated mineral water in healthy postmenopausal women
}

\author{
Stefanie Schoppen ${ }^{1}$, Ana M. Pérez-Granados ${ }^{1}$, Ángeles Carbajal ${ }^{2}$, Concepción de la Piedra ${ }^{3}$ and M. Pilar \\ Vaquero ${ }^{1}$ \\ ${ }^{1}$ Department of Metabolism and Nutrition, Instituto del Frío, Spanish Council for Scientific Research (CSIC), C/José Antonio Novais 10, \\ 28040-Madrid, Spain \\ ${ }^{2}$ Department of Nutrition, Faculty of Pharmacy, Madrid Complutense University, Madrid, Spain \\ ${ }^{3}$ Laboratory of Bone Pathophysiology, Fundación Jimenez Díaz, Madrid, Spain
}

(Received 3 June 2004 - Revised 20 September 2004 - Accepted 18 October 2004)

\begin{abstract}
This study was designed to investigate the possible effects of consuming Na-rich carbonated mineral water on bone remodelling and urinary mineral excretion in postmenopausal women. Women ( $n$ 18) included were amenorrhoeic ( $>1$ year), healthy and not obese (BMI $\left.<30 \mathrm{~kg} / \mathrm{m}^{2}\right)$. No woman was taking oestrogen replacement therapy, mineral and vitamin supplements, phyto-oestrogens or medications known to affect bone and lipid metabolism. In two consecutive interventions that lasted 8 weeks each, women drank 1 litre of control mineral water daily and 1 litre of carbonated mineral water, rich in $\mathrm{Na}, \mathrm{HCO}_{3}^{-}$and $\mathrm{Cl}^{-}$, daily. Body weight and height were measured, BMI was calculated and blood pressure was measured. Blood samples were taken from fasting subjects and serum obtained to analyse the biochemical bone markers, procollagen I amino-terminal propeptide (PINP) and $\beta$-carboxy-terminal telopeptide of collagen ( $\beta$-CTX). At the end of each period, $24 \mathrm{~h}$ urine samples were collected to determine $\mathrm{Ca}, \mathrm{Mg}, \mathrm{P} \mathrm{Na}^{+}, \mathrm{K}^{+}, \mathrm{Cl}^{-}$, urine excretion and urinary $\mathrm{pH}$. No changes in body weight, BMI or blood pressure were observed during the experimental period. Ca excretion was lower after the intake of carbonated water than after intake of the control water $(P=0.037)$ while $\mathrm{P}$ excretion was higher $(P=0.015)$. Total urine, Na and $\mathrm{Cl}^{-}$excretion did not differ between the two periods but urinary $\mathrm{pH}$ was increased after the intake of carbonated mineral water. PINP and $\beta$-CTX did not differ between the two periods. Daily consumption of 1 litre of Na-rich carbonated mineral water for 8 weeks does not affect bone remodelling in healthy postmenopausal women.
\end{abstract}

Carbonated mineral water: Bone remodelling: Postmenopausal women: $\mathrm{NaHCO}_{3}$ : Urinary calcium excretion

Over the centuries, many cultures have ascribed healthy properties to natural spring waters. Many of these spring waters are rich in mineral salts, which have numerous beneficial effects on bone metabolism, in particular owing to their $\mathrm{Ca}$ and $\mathrm{Mg}$ content (Cepollaro et al. 1996; Van Dokkum et al. 1996; Aptel et al. 1999; Böhmer et al. 2000; Guillemant et al. 2000; Siener et al. 2004). Certain mineral waters, however, also supply large amounts of other bone-protective ions, such as $\mathrm{HCO}_{3}^{-}$and $\mathrm{K}^{+}$. Some studies have shown that the administration of $\mathrm{KHCO}_{3}$, in different forms, improves Ca balance (Buclin et al. 2001; Frasetto et al. 2001; Maurer et al. 2003). In contrast, Na intake, in the form of table salt, is known to increase bone resorption and induce urinary $\mathrm{Ca}$ loss, especially in postmenopausal women (Goulding, 1990; Devine et al. 1995; Evans et al. 1997). Nevertheless, Ginty et al. (1998) reported that young women adapt by increasing $\mathrm{Ca}$ absorption to avoid bone loss.

The type and mineralization of the water consumed will determine its mechanisms of action and specific effects. There is no information concerning the possible influence of drinking Na-rich waters on bone health.
The imbalance of acid- and base-forming nutrients in the modern diet is currently under discussion. Bone tissue acts as a buffer, playing a significant role in controlling the acid-base equilibrium of blood and extracellular fluid. Some authors point out that the Western diet increases the net systemic acid load because of its high content of acidifying compounds such as animal protein (Buclin et al. 2001; Bushinsky, 2001; Frasetto et al. 2001; New, 2002; Massey, 2003). This may negatively affect $\mathrm{Ca}$ metabolism and accelerate bone resorption. However, the combination of food components plays an important role in relation to the content of acidifying compounds. The large amount of $\mathrm{Ca}$ in milk, for example, compensates for the negative effect of milk protein, and the large quantity of alkali-forming nutrients (e.g. $\mathrm{Mg}$ and $\mathrm{K}$ ) in plant foods can act as a buffer instead of using bone carbonate (Tucker et al. 1999). Bone is a dynamic tissue characterized by two opposite processes: resorption and formation. The biochemical markers of bone remodelling present in serum and urine provide an index of osteoclast and osteoblast activity (Seibel, 2000). However, serum markers of bone remodelling, procollagen I amino-terminal propeptide 
(PINP; formation) and $\beta$-carboxy-terminal telopeptide of collagen $(\beta-C T X$; resorption), show lower biological variability than urinary markers (Alvarez et al. 2000).

Our research group recently observed that drinking Na-rich carbonated mineral water reduces cardiovascular risk in postmenopausal women (Schoppen et al. 2004). Because risk of osteoporosis is also very important in this population group, the aim of the present study was to investigate the effects of consumption of the same Na-rich carbonated mineral water on bone remodelling.

\section{Subjects and methods}

\section{Subjects}

Eighteen postmenopausal women, mean age 53 (SD 3) years, of the Madrid City Council's Food and Health Department Menopause Program, participated in the present study. Women in this prevention programme periodically undergo clinical evaluation by means of anthropometric measurements, blood tests, bone mineral density (BMD) determination and mammography. The average time since menopause was 3.7 years. After being informed of the study conditions by physicians, the women were interviewed to determine their habitual dietary intake. Individuals selected for the study had to be healthy and amenorrhoeic for at least 1 year. In addition, study participants could not be obese (BMI $<30 \mathrm{~kg} / \mathrm{m}^{2}$ ) or be receiving oestrogen replacement therapy or any other medication known to affect bone and lipid meta-bolism, nor be taking vitamin, mineral or phyto-oestrogen supplements. We used the World Health Organization (1994) definition of osteoporosis as a diagnostic criterion. Women whose BMD $\mathrm{T}$ score was $-2.5 \mathrm{SD}$ or less were excluded from the study, as were those who had followed a weight-loss diet during the previous year. The study was approved by the Ethics Committee of the Spanish Council for Scientific Research.

\section{Study design}

The study consisted of two consecutive 8-week intervention periods during the cold season. Women drank 1 litre of a control mineral water daily during the first period and 1 litre of the carbonated mineral water daily in the following period. Both mineral waters were provided in $0 \cdot 5$-litre bottles by Vichy Catalán, SA (Barcelona, Spain). A blind study was not carried out because the two mineral waters differed in appearance, owing to the carbonic gas content of the study water, and also because volunteers were in contact with each other. As a result, we decided to apply a well-controlled sequential design, starting the water treatment in all women simultaneously. The carbonated mineral water was rich in $\mathrm{HCO}_{3}^{-}, \mathrm{Na}^{+}$and $\mathrm{Cl}^{-}$while the control water had a low mineral content (Table 1).

\section{Dietary intake and compliance control}

Dietary intake was evaluated to determine habitual energy and nutrient intakes and to detect possible dietary changes that could interfere with mineral and bone metabolism. A trained dietitian recorded the dietary intake of all volunteers through a validated version of the dietary history in a personal interview at the beginning of the control period. The women also completed a $3 \mathrm{~d}$ record corresponding to the last three days of the carbonated
Table 1. Composition of the mineral waters used in the present study in $\mathrm{mg} / \mathrm{l}$ $(\mathrm{mmol} / \mathrm{l})$

\begin{tabular}{lcrr}
\hline Component & $\begin{array}{c}\text { Carbonated } \\
\text { water }\end{array}$ & \multicolumn{1}{c}{$\begin{array}{c}\text { Control } \\
\text { water }\end{array}$} & $\begin{array}{c}\text { Carbonated/ } \\
\text { control }\end{array}$ \\
\hline $\mathrm{HCO}_{3}^{-}$ & $2094.4(34.34)$ & $71.1(1 \cdot 17)$ & 29.5 \\
$\mathrm{Cl}^{-}$ & $583.0(16.44)$ & $5.7(0.16)$ & 102.3 \\
$\mathrm{SO}_{4}^{2-}$ & $49.9(0.52)$ & $15.7(0.18)$ & 3.2 \\
$\mathrm{~F}^{-}$ & $7.9(1.0)$ & $0.2(0.01)$ & 39.5 \\
$\mathrm{Ca}^{2+}$ & $43.6(1.09)$ & $25.2(0.63)$ & 1.7 \\
$\mathrm{Mg}^{2+}$ & $5.7(0.24)$ & $2.7(0.11)$ & 2.1 \\
$\mathrm{Na}^{+}$ & $1116.5(48.57)$ & $9.0(0.39)$ & 124.1 \\
$\mathrm{~K}^{+}$ & $54.7(1.4)$ & $1.4(0.04)$ & 39.1 \\
\hline
\end{tabular}

water period. Two dietary histories were not performed because this technique is repeated only in long-term studies. Previous reports indicate that the food intake data obtained by the dietary history coincides with that of the $3 \mathrm{~d}$ record (de Groot et al. 1996; Schroll et al. 1996). The dietary history consisted of questions on the frequency of consumption of foods during the preceding month. Portion sizes were precisely assessed by weighing and also through the use of a photo book (Abbott, 1997), from which only pictures of the dishes corresponding to Spanish dietary habits were used. Dietary food and nutrient intakes, energy provided by macronutrients and the ratios vegetable protein:animal protein and Ca:protein were calculated (Moreiras et al. 2001). Water compliance was assessed using a specific questionnaire after each water period and by personal telephone interviews throughout the whole intervention.

\section{Physical activity and sun exposure}

A physical activity questionnaire was administered that included representative values expressed as multiples of resting energy expenditure. Average daily exercise was calculated taking into account the intensity level and time spent on each activity. Activities were divided in five categories (resting, very light, light, moderate and heavy; Aranceta \& Serra Majem 2001). Questions on sunlight exposure concerned the amount of time spent in the open air during the day and the clothes worn when outdoors.

\section{Anthropometric, blood pressure and bone mineral density determinations}

At the beginning of the study and after each intervention period, weight and height were measured by trained personnel. BMI was calculated by dividing weight in $\mathrm{kg}$ by the square of height in $\mathrm{m}$. Systolic and diastolic blood pressures were also determined. At the beginning of the study BMD was determined in the lumbar spine and the femoral neck by dual-energy X-ray absorptiometry (Hologic QDR-1000 instrument; Hologic, Waltham, MA, USA). The $\mathrm{T}_{30}$ score, defined as (measured BMD minus mean population BMD at age 30)/SD, was calculated (mean population BMD from Díaz Curiel et al. 1997).

\section{Biochemical determinations in blood and urine}

Blood samples were collected by venepuncture between 08.00 and 08.30 hours, after a $12 \mathrm{~h}$ fast. Serum was separated by centrifugation for $15 \mathrm{~min}$. Samples were aliquoted and frozen at $-60^{\circ} \mathrm{C}$ until use. The biochemical bone markers $\beta$-CTX and 
PINP were determined in serum by electrochemiluminescence (Garnero et al. 2001) and RIA (Melkko et al. 1996) techniques, respectively, using commercially available kits. Determination of $\beta$-CTX was performed with the Elecsys ${ }^{\circledR} \beta$ CrossLaps/serum assay in an Elecsys 2010 automated analyser (Roche Diagnostics, Mannheim, Germany), while PINP was assayed with a kit from Orion Diagnostica (Spoo, Finland). Inter-assay CV for $\beta$-CTX and PINP were $<6 \%$ and $10 \%$, respectively; and sensitivity $0.01 \mu \mathrm{g} / \mathrm{l}$ and $2 \mu \mathrm{g} / \mathrm{l}$, respectively.

At the end of each period, $24 \mathrm{~h}$ urine samples were collected. Subjects were given detailed verbal and written instructions on how to collect a complete $24 \mathrm{~h}$ urine sample and given a 2-litre sterile plastic bottle to take with them; only one $24 \mathrm{~h}$ urine collection was performed after each intervention to ensure volunteer collaboration. Urinary $\mathrm{Ca}$ and $\mathrm{Mg}$ were determined by atomic absorption spectrometry (1100B spectrometer; PerkinElmer, Norwalk, CT, USA) and urinary P by photocolorimetry (PU8620 UV/ VIS/NIR spectrophotometer; Philips Scientific and Analytical Equipment, Eindhoven, The Netherlands). Quantitative urine control (Lyphochek ${ }^{\circledR}$; Bio-Rad Diagnostics Group, Irvine, CA, USA) was used to assess precision. $\mathrm{Na}^{+}, \mathrm{Cl}^{-}$and $\mathrm{K}^{+}$were determined in $24 \mathrm{~h}$ urine with an electrolyte analyser $\left(\mathrm{EML}^{\mathrm{TM}} 100\right.$ Electrolyte Laboratory; Radiometer Copenhagen, Radiometer Medical A/S, Brønshøj, Denmark). Urine samples were diluted 2:1 (urine:diluent) with diluent for urine S2490 (Radiometer Copenhagen). Qualitycheck ${ }^{\mathrm{TM}}$ S2480 and S2470 (Radiometer Copenhagen) were used as internal standards to assess precision. $\mathrm{Na}^{+}, \mathrm{Cl}^{-}$ and $\mathrm{K}^{+}$were determined in one run. The inter-assay $\mathrm{CV}$ for $\mathrm{Ca}$, $\mathrm{Mg}$ and $\mathrm{P}$ were $0.50,1.13$ and $1.72 \%$, respectively.

\section{Statistical analyses}

Results are presented as mean values and standard deviations. Data were analysed by one-factor repeated-measures ANOVA. Differences were considered significant at $P<0 \cdot 05$. The SPSS statistical package version 11.0 (SPSS Inc., Chicago, IL, USA) was used to analyse the data.

\section{Results}

\section{Dietary assessment}

Compliance rate was high, $83 \%$ in the control water period and $77 \%$ in the carbonated water period. Energy intake did not vary throughout the entire study. In addition, no differences were observed in the ratios vegetable protein:animal protein and Ca:protein, and in protein, carbohydrate, fat, fibre or mineral intake, between the two periods (Table 2).

\section{Physical activity and sun exposure}

Physical activity of the women was moderate: activity factor 1.63 (SD 0.1; FAO/WHO/UNU, 1985). Sun exposure habits, as recorded by the general questionnaire, were quite high. The women walked on average for $1 \mathrm{~h}$ daily. Only two of the women preferred to stay out of direct sunlight, but all wore short sleeves and bathing suits in the summer.

\section{Anthropometric data, blood pressure and bone mineral density}

There were no differences in anthropometry and blood pressure between the two periods. Specifically, body weight was 63.5 (SD 8.0) v. 63.4 (SD 8.1) kg, BMI was 24.4 (SD 6.8) v. 24.3 (SD $6 \cdot 8) \mathrm{kg} / \mathrm{m}^{2}$ and systolic/diastolic blood pressure was $132 / 79$ (SD
Table 2. Energy and nutrient intakes of the eighteen postmenopausal women who consumed 1 litre of control and carbonated water daily, for 8 weeks each* (Mean values with their standard deviations)

\begin{tabular}{|c|c|c|c|c|}
\hline & \multicolumn{2}{|c|}{ Control water } & \multicolumn{2}{|c|}{ Carbonated water } \\
\hline & Mean & SD & Mean & $\mathrm{SD}$ \\
\hline Energy (kJ/d) & 8699 & 1866 & 8526 & 1318 \\
\hline Protein $(\mathrm{g} / \mathrm{d})$ & 96 & 28 & 97 & 20 \\
\hline Animal protein $(\mathrm{g} / \mathrm{d})$ & 70 & 26 & 72 & 21 \\
\hline Vegetable protein $(\mathrm{g} / \mathrm{d})$ & 26 & 8 & 25 & 6 \\
\hline $\begin{array}{l}\text { Vegetable } \\
\text { protein:animal protein }\end{array}$ & 0.41 & 0.17 & 0.39 & 0.17 \\
\hline Lipid $(g / d)$ & 86 & 27 & 88 & 18 \\
\hline Fibre $(g / d)$ & $21 \cdot 2$ & 6 & $19 \cdot 7$ & 6 \\
\hline $\mathrm{Ca}(\mathrm{mg} / \mathrm{d})$ & 1085 & 471 & 1111 & 466 \\
\hline $\mathrm{Ca}(\mathrm{mg} / \mathrm{d})$ :protein $(\mathrm{g} / \mathrm{d})$ & $11 \cdot 25$ & 3.14 & 11.62 & 4.43 \\
\hline $\mathrm{K}^{+}(\mathrm{mg} / \mathrm{d})$ & 3511 & 700 & 3044 & 501 \\
\hline $\mathrm{Mg}(\mathrm{mg} / \mathrm{d})$ & 306 & 72 & 301 & 54 \\
\hline$P(\mathrm{mg} / \mathrm{d})$ & 1258 & 457 & 1313 & 530 \\
\hline Vitamin C (mg/d) & 178 & 81 & 163 & 57 \\
\hline Vitamin D $(\mu \mathrm{g} / \mathrm{d})$ & 4.69 & $2 \cdot 31$ & 5.99 & 9.04 \\
\hline
\end{tabular}

*The variables did not differ between the control and the carbonated water intervention periods.

15/9) v. 123/77 (SD 16/9) mmHg for the control water period $v$. the carbonated water period, respectively.

The BMD $\mathrm{T}_{30}$ scores for the lumbar spine and the femoral neck were -0.99 (SD 1.07) and -0.79 (SD 0.83), respectively.

Urinary $\mathrm{pH}, 24 \mathrm{~h}$ urine excretion, urinary mineral excretion and serum bone markers

Urinary $\mathrm{pH}$ was significantly higher after the intake of carbonated water than after intake of the control water $(P<0.001)$, but $24 \mathrm{~h}$ urine excretion did not differ between the two periods. Ca excretion was significantly lower $(P=0.037)$ after the intervention with carbonated mineral water than at the end of the control water intervention, while $\mathrm{P}$ excretion was significantly higher $(P=0 \cdot 015) . \mathrm{Mg}, \mathrm{Na}^{+}, \mathrm{K}^{+}$and $\mathrm{Cl}^{-}$values did not differ between the two periods, nor did the values of the bone turnover biomarkers ( $\beta$-CTX and PINP; Table 3).

\section{Discussion}

The present study describes, for the first time, the effects of an alkaline carbonated mineral water on Ca urinary losses and bone remodelling. This water combines ions with positive and negative influence on bone, and should be considered a food item that provides new aspects to study the effects of a combination of ions on bone. The main limitation of this study was that the participants were free-living subjects and their daily dietary intake was not standardized.

However, consumption patterns of the subjects of the present study closely resemble those of the traditional Mediterranean diet, whose health benefits have been demonstrated repeatedly (Trichopoulou \& Lagiou, 1997; Carbajal \& Ortega, 2001). Mean $\mathrm{Ca}$ intake was appropriate, although the range was wide. The ratios vegetable protein:animal protein and Ca:protein were similar to those of other studies (Alaimo et al. 1994; McDowell et al. 1994; Smit et al. 1999; Neville et al. 2002). In addition, these women exercised regularly and maintained appropriate 
Table 3. Urine excretion and $\mathrm{pH}$, urinary mineral excretion and biomarkers of bone remodelling of postmenopausal women who consumed control and carbonated water for 8 weeks each

(Mean values with their standard deviation for eighteen women)

\begin{tabular}{|c|c|c|c|c|c|}
\hline & \multicolumn{2}{|c|}{ Control water } & \multicolumn{2}{|c|}{ Carbonated water } & \multirow{2}{*}{$\begin{array}{l}\text { Repeated-measures } \\
\text { ANOVA } P \text { value }\end{array}$} \\
\hline & Mean & SD & Mean & SD & \\
\hline Urine excretion (ml/d) & 2542 & 1046 & 2806 & 1090 & NS \\
\hline Urinary $\mathrm{pH}$ & $6 \cdot 1$ & 0.46 & $6 \cdot 76^{\star \star *}$ & $0.34^{\star * *}$ & $<0.0001$ \\
\hline \multirow{2}{*}{$\begin{array}{l}\text { Urinary Ca excretion }(\mathrm{mmol} / \mathrm{l}) \\
(\mathrm{mg} / \mathrm{d})\end{array}$} & $4 \cdot 12$ & $1 \cdot 28$ & $3.48^{\star}$ & $1 \cdot 39$ & 0.037 \\
\hline & $164 \cdot 99$ & $51 \cdot 16$ & $139 \cdot 41^{*}$ & $55 \cdot 52$ & \\
\hline \multirow{2}{*}{$\begin{array}{l}\text { Urinary Mg excretion }(\mathrm{mmol} / \mathrm{l}) \\
(\mathrm{mg} / \mathrm{d})\end{array}$} & $3 \cdot 20$ & 1.33 & 3.26 & 1.29 & NS \\
\hline & $77 \cdot 84$ & $32 \cdot 37$ & $79 \cdot 22$ & 31.27 & \\
\hline \multirow{2}{*}{$\begin{array}{l}\text { Urinary P excretion (mmol/l) } \\
(\mathrm{mg} / \mathrm{d})\end{array}$} & 26.94 & $5 \cdot 66$ & $33 \cdot 34^{*}$ & 9.68 & 0.015 \\
\hline & $834 \cdot 29$ & $175 \cdot 38$ & $1032 \cdot 71^{*}$ & $299 \cdot 89$ & \\
\hline \multirow{2}{*}{$\begin{array}{l}\text { Urinary } \mathrm{Na}^{+} \text {excretion }(\mathrm{mmol} / \mathrm{l}) \\
(\mathrm{mg} / \mathrm{d})\end{array}$} & $52 \cdot 06$ & $25 \cdot 28$ & $59 \cdot 17$ & 28.55 & NS \\
\hline & $1196 \cdot 75$ & $581 \cdot 18$ & $1360 \cdot 23$ & $656 \cdot 28$ & \\
\hline \multirow{2}{*}{$\begin{array}{l}\text { Urinary } \mathrm{Cl}^{-} \text {excretion }(\mathrm{mmol} / \mathrm{l}) \\
(\mathrm{mg} / \mathrm{d})\end{array}$} & $60 \cdot 14$ & 24.92 & 63.39 & 23.75 & NS \\
\hline & $2132 \cdot 10$ & 883.33 & $2247 \cdot 33$ & 841.93 & \\
\hline \multirow{2}{*}{$\begin{array}{l}\text { Urinary } \mathrm{K}^{+} \text {excretion }(\mathrm{mmol} / \mathrm{l}) \\
(\mathrm{mg} / \mathrm{d})\end{array}$} & 19.95 & 8.82 & $20 \cdot 42$ & 8.31 & NS \\
\hline & 779.90 & $344 \cdot 69$ & $798 \cdot 37$ & $324 \cdot 72$ & \\
\hline Serum $\beta$-CTX $(\mu \mathrm{g} / \mathrm{l})$ & 0.47 & 0.14 & 0.44 & 0.17 & NS \\
\hline Serum PINP $(\mu \mathrm{g} / \mathrm{l})$ & $40 \cdot 9$ & $12 \cdot 6$ & $42 \cdot 6$ & $19 \cdot 9$ & NS \\
\hline
\end{tabular}

$\beta$-CTX, $\beta$-carboxy-terminal telopeptide of collagen I; PINP, procollagen I amino-terminal propeptide.

Means values are significantly different from those of the control water period, ${ }^{\star} P<0.05 ;{ }^{* \star} P<0.01$; ${ }^{\star \star \star} P \leq 0.001$

body weight. More details concerning dietary intakes have been published elsewhere (Schoppen et al. 2004).

After consumption of 1 litre carbonated mineral water/d, $24 \mathrm{~h}$ urine $\mathrm{Ca}$ excretion was lower than after the control water period, and no changes in the bone remodelling biomarkers were observed between the two periods. The main difference between the two mineral waters used in the study involved their $\mathrm{Na}^{+}, \mathrm{HCO}_{3}^{-}$and $\mathrm{Cl}^{-}$contents. There is evidence that a high $\mathrm{Na}$ intake increases urinary $\mathrm{Ca}$ excretion through a mechanism involving coupled transport of $\mathrm{Na}^{+}$and $\mathrm{Ca}$ in the nephron (Goulding, 1990). Consequently, high levels of dietary Na can affect bone resorption and BMD (Devine et al. 1995; Evans et al. 1997; Lin et al. 2003; Tilney et al. 2003). Consumption of the carbonated water added about $1 \mathrm{~g}(50 \mathrm{mmol}) \mathrm{Na} / \mathrm{d}$ to the diet. However, after its consumption, total urinary excretion, urinary $\mathrm{Na}^{+}$and $\mathrm{Cl}^{-}$did not increase significantly. $\mathrm{Na}$ excretion was low in both water periods (Evans et al. 1997), which indicates low $\mathrm{Na}$ intake (Willett, 1998), and Schoppen et al. (2004) recently suggested that a supplement of $\mathrm{Na}$ in the form of this water might have beneficial effects in these women, e.g. on lipoprotein metabolism. Therefore, to reassess the present results and investigate the mechanisms involved, an acute, diet-controlled assay should be performed.

As dietary $\mathrm{Ca}$ intake was $>1000 \mathrm{mg} / \mathrm{d}$, this extra $\mathrm{Na}$ from the water may have been insufficient to increase urinary $\mathrm{Ca}$. Moreover, $\mathrm{Ca}$ excretion with the carbonated water was reduced, which suggests that other ions in the water may have counteracted the effects of $\mathrm{Na}$. One litre of the carbonated water also supplied $2 \mathrm{~g}(34 \mathrm{mmol}) \mathrm{HCO}_{3}^{-} / \mathrm{d}$ to the diet. This anion tends to reduce some of the negative effects of $\mathrm{NaCl}$ on $\mathrm{Ca}$ excretion (Lemann et al. 1991), as well as on arterial pressure (Luft et al. 1990; Schorr et al. 1996). In addition, it reduces the calciuric effects of $\mathrm{Na}$ by increasing renal $\mathrm{Ca}$ reabsorption in the distal tubules (Goulding, 1990; Barzel \& Massey, 1998). Lemann et al. (1991) observed that consumption of $90 \mathrm{mmol} \mathrm{KHCO}_{3} / \mathrm{d}$ in a young population reduced urinary $\mathrm{Ca}$ excretion and improved $\mathrm{Ca}$ balance. Moreover, supplements of $60-120 \mathrm{mmol} \mathrm{KHCO}_{3} / \mathrm{d}$ were sufficient to neutralize endogenous acid, delay bone resorption and increase the bone formation ratio in postmenopausal women (Sebastian et al. 1994). The carbonated mineral water of the present study supplied quantities of $\mathrm{HCO}_{3}^{-}$similar to those of previous investigations. Values of urinary $\mathrm{Ca}$ excretion reported herein were similar to those of Buclin et al. (2001) and lower than those of Kessler \& Hesse (2000), both studies being conducted in young men who consumed 2 litres carbonated mineral water/d (3000 and $1715 \mathrm{mg} \mathrm{HCO}_{3}^{-} / 1$, respectively).

$\mathrm{P}$ status is not as strictly regulated as that of $\mathrm{Ca}$, and $\mathrm{P}$ intake is usually much higher than recommended. In the present study it was approximately double the estimated average requirement (Department of Health, 1991; Institute of Medicine of the National Academies, 1997), and therefore increased P losses may not be relevant in this group. A parallel relationship between urinary and dietary $\mathrm{P}$ is known to exist, but the diet of the postmenopausal volunteers was very stable throughout the study. $\mathrm{P}$ intake during the last $24 \mathrm{~h}$ of the control and carbonated water intake periods, corresponding with the urine collection day, was very similar (1239 (SD 598) and 1140 (SD 336) mg, respectively) and coincided with the intake values obtained by the dietary history. In rats fed an alkalogenic diet induced by $\mathrm{KHCO}_{3}$, urinary $\mathrm{P}$ did not vary compared with a neutral diet (Lina \& Kuijpers, 2004). This suggests that the effect observed was related to ions other than $\mathrm{K}^{+}$and $\mathrm{HCO}_{3}^{-}$. Therefore, further investigation is needed on the relationship between the ions ingested and renal handling of $\mathrm{P}$.

The biochemical marker of bone formation chosen in the present study was PINP, a very sensitive collagen-formation indicator used to study bone turnover in postmenopausal osteoporosis (Domínguez et al. 1998). The biochemical marker of bone resorption used was $\beta$-CTX. In recently synthesized collagen, the $\mathrm{C}$-terminal telopeptide is linear ( $\alpha$ form), but the degree of $\beta$ isomerization increases with age of the collagen molecules (Fledelius et al. 1997; Garnero et al. 2001). Previous studies of postmenopausal osteoporosis (de la Piedra et al. 1997) have demonstrated that $\beta$-CTX is a very sensitive resorption marker 
for this population. PINP and $\beta$-CTX levels found in the present study were similar to those reported by other authors in healthy age-matched women (Melkko et al. 1996; Garnero et al. 2001).

The carbonated water used in the present study, with its alkaline properties, decreased urinary $\mathrm{Ca}$ excretion but did not improve bone formation over resorption. This water also plays an alkaline role in the digestive tract (Vaquero et al. 2001; Schoppen et al. 2003) and it is possible that Ca absorption decreased as a result of the lower solubility associated with a higher digestive tract $\mathrm{pH}$. In that case, the reduction in urinary $\mathrm{Ca}$ loss would represent a compensatory mechanism. This hypothesis is compatible with the involvement of $\mathrm{HCO}_{3}^{-}$ions. Nevertheless, the effect of this carbonated water on $\mathrm{Ca}$ absorption and renal function, particularly in vulnerable individuals, is an important issue for new research.

Our group recently observed that this water reduced cardiovascular risk in these postmenopausal women (Schoppen et al. 2004). Those findings, together with the present results, support the link between cardiovascular and osteoporosis risk factors (Qi et al. 2003; Masse et al. 2004; McFarlane et al. 2004). In fact, a current issue in relation to bone health is the imbalance between acid- and alkaline-forming foods in the modern diet. It is generally assumed that the relatively high $\mathrm{S}$ content of meat may lead to an endogenous acid load that contributes to bone loss, while high intake levels of fruits and vegetables may protect bone health in elderly persons (Tucker et al. 1999); these foods show also negative and positive influences on cardiovascular risk. The results of the present study suggest that habitual consumption of a mineral water rich in $\mathrm{Na}$ and $\mathrm{HCO}_{3}^{-}$may contribute to a more alkaline diet, with its corresponding health benefits.

The results indicate that daily consumption of 1 litre of a carbonated mineral water, that supplies $1 \mathrm{~g} \mathrm{Na}, 2 \mathrm{~g} \mathrm{HCO}_{3}^{-}$and very low amounts of $\mathrm{Ca}$ and $\mathrm{Mg}$, does not affect bone remodelling in healthy postmenopausal women.

\section{Acknowledgements}

This study was supported by Vichy Catalán SA (Spain) and fellowships from the German Academic Exchange Service, the Spanish Council for Scientific Research and the Comunidad de Madrid. The authors thank the study volunteers and staff from the Food and Health Department of Madrid City Council, especially F. Vivas; C. González-Vizcaíno and I. Sánchez-Arcilla. They also thank L. Barrios for her statistical advice.

\section{References}

Abbott M [editor] (1997). Portion Photos of Popular Foods. Stout, WI: The American Dietetic Association and Centre for Nutrition Education, University of Wisconsin.

Alaimo K, McDowell MA, Briefel RR, Bischof AM, Caughman CR, Loria CM \& Johnson CL (1994) Dietary intakes of vitamins, minerals and fiber of persons ages 20 months and over in the United States: Third National Health and Nutrition Examination Survey (NHANES), Phase 1, 1988-91. Advance Data from Vital and Health Statistic, no. 258. Hyattsville, MD: National Center for Health Statistics.

Alvarez L, Ricos C, Peris P, GuaNabens N, Monegal A, Pons F \& Ballesta AM (2000) Components of biological variation of biochemical markers of bone turnover in Paget's bone disease. Bone 26, 571-576.

Aptel I, Cance-Rouzaud A \& Grandjean H (1999) Association between calcium ingested from drinking water and femoral bone density in elderly women: evidence from the EPIDOS cohort. $J$ Bone Miner Res 14, 829-833.

Aranceta J \& Serra-Majem L (2001) Estructura general de las guías alimentarias para la población española. Decálogo para una dieta saludable. (General structure of the Spanish population food guides. A decalogue for a healthy diet). In Guías Alimentarias para la Población Española, pp. 183-194 [Sociedad Española de Nutrición Comunitaria, editors]. Madrid: IM\&C.

Barzel US \& Massey LK (1998) Excess dietary protein can adversely affect bone. $J$ Nutr 128, 1051-1053.

Böhmer H, Müller H \& Resch KL (2000) Calcium supplementation with calcium rich mineral waters: a systematic review and meta-analysis of its bioavailability. Osteoporos Int 11, 938-943.

Buclin T, Cosma M, Appenzeller M, Jacquet AF, Decosterd LA, Biollaz J \& Burckhardt P (2001) Diet acids and alkalis influence calcium retention in bone. Osteoporos Int 12, 439-499.

Bushinsky DA (2001) Acid-base imbalance and the skeleton. Eur J Nutr 40, 238-244.

Carbajal A \& Ortega RM (2001) La dieta mediterránea como modelo de dieta prudente y saludable (The Mediterranean diet as model for a prudent and healthy diet). Rev Chil Nutr 28, 224-236.

Cepollaro C, Orlandi G, Gonnelli S, Ferrucci G, Arditti JC, Borracelli D, Toti E \& Gennari C (1996) Effect of calcium supplementation as a high-calcium mineral water on bone loss in early postmenopausal women. Calcif Tissue Int 59, 238-239.

De Groot CPGM, van Staveren WA, Dirren H \& Hautvast JGAJ (1996) Summary and conclusions of the report on the second data collection period and longitudinal analyses of the SENECA study. Eur J Clin Nutr 50, S123-S124.

De la Piedra C, Traba ML, Domínguez C \& Sosa M (1997) New biological markers of bone resorption in the study of postmenopausal osteoporosis. Clin Chim Acta 265, 225-234.

Department of Health (1991) Dietary Reference Values for Food Energy and Nutrients for the United Kingdom. Report on Health and Social Subjects no. 41. London: HMSO.

Devine A, Criddle AR, Dick IM, Kerr DA \& Prince RL (1995) A longitudinal study of the effect of sodium and calcium intakes on regional bone density in postmenopausal women. Am J Clin Nutr 62, $740-745$.

Díaz Curiel M, Carrasco de la Peña JL, Honorato Pérez J, Pérez Cano R, Rapado A \& Ruiz Martínez I (1997) Study of bone mineral density in lumbar spine and femoral neck in a Spanish population. Osteoporosis Int 7, 59-64.

Domínguez C, Sosa M, Traba ML, Alvarez E \& de la Piedra C (1998) Biochemical markers of bone formation in the study of postmenopausal osteoporosis. Osteoporos Int 8, 147-151.

Evans CE, Chughtai AY, Blumsohn A, Gils M \& Eastell R (1997) The effect of dietary sodium on calcium metabolism in premenopausal and postmenopausal women. Eur J Clin Nutr 51, 394-399.

Food and Agriculture Organization/World Health Organization/United Nations University (1985) Energy and Protein Requirements. Technical Report Series no. 724. Geneva: WHO.

Fledelius C, Johnsen AH, Cloos PA, Bonde M \& Qvist P (1997) Characterization of urinary degradation products derived from type I collagen. Identification of a $\beta$-isomerized Asp-Gly sequence within the C-terminal telopeptide $(\alpha 1)$ region. J Biol Chem 272, 9755-9763.

Frasetto L, Morris RC Jr, Sellmeyer DE, Todd K \& Sebastian A (2001) Diet, evolution and aging - the pathophysiologic effects of the post agricultural inversion of the potassium-to-sodium and base-to-chloride ratios in the human diet. Eur J Nutr 40, 200-213.

Garnero P, Borel O \& Delmas PD (2001) Evaluation of a fully automated serum assay for C-terminal cross-linking telopeptide of type I collagen in osteoporosis. Clin Chem 47, 694-702.

Ginty F, Flynn A \& Cashman KD (1998) The effect of dietary sodium intake on biochemical markers of bone metabolism in young women. Br J Nutr 79, 343-350. 
Goulding A (1990) Osteoporosis: why consuming less sodium chloride helps to conserve bone. $N Z$ Med J 103, 120-122.

Guillemant J, Le HT, Accarie C, du Montcel ST, Delabroise AM, Arnaud MJ \& Guillemant S (2000) Mineral water as a source of dietary calcium: acute effects on parathyroid function and bone resorption in young men. Am J Clin Nutr 71, 999-1002.

Institute of Medicine of the National Academies (1997) Dietary Reference Intakes for Calcium, Phosphorous, Magnesium, Vitamin D, and Fluoride, p. 175. Washington, DC: National Academic Press.

Kessler T \& Hesse A (2000) Cross-over study of the influence of bicarbonate-rich mineral water on urinary composition in comparison with sodium potassium citrate in healthy male subjects. $\mathrm{Br} J$ Nutr 84, $865-871$.

Lemann J Jr, Pluess J, Gray RW \& Hoffmann RG (1991) Potassium administration reduces and potassium deprivation increases urinary calcium excretion in healthy adults. Kidney Int 39, 973-983.

Lin PH, Ginty F, Appel LJ, Aickin M, Bohannon A, Garnero P, Barclay D \& Svetkey LP (2003) The DASH diet and sodium reduction improve markers of bone turnover and calcium metabolism in adults. $J$ Nutr 133, 3130-3136.

Lina BAR \& Kuijpers MHM (2004) Toxicity and carcinogenic or alkalogenic diets in rats; effects of feeding $\mathrm{NH}_{4} \mathrm{Cl}, \mathrm{KHCO}_{3}$ or $\mathrm{KCl}$. Food Chem Toxicol 42, 135-153.

Luft FC, Zemel MB, Sowers JA, Fineberg NS \& Weinberger MH (1990) Sodium bicarbonate and sodium chloride: effects on blood pressure and electrolyte homeostasis in normal and hypertensive man. J Hypertens $\mathbf{8}$, 663-670.

McDowell MA, Briefel RR, Alaimo K, Bischof AM, Caughman CR, Carroll MD, Loria CM \& Johnson CL (1994) Energy and macronutrient intakes of persons aged 20 months and over in the United States: Third National Health and Nutrition Examination Survey (NHANES), Phase 1, 1988-91. Advance Data from Vital and Health Statistics no. 255. Hyattsville, MD: National Center for Health Statistics.

McFarlane SI, Muniyappa R, Shin JJ, Bahtiyar G \& Sowers JR (2004) Osteoporosis and cardiovascular disease: brittle bones and boned arteries, is there a link? Endocrine 23, 1-10.

Masse PG, Dosy J, Tranchant CC \& Dallaire R (2004) Dietary macro- and micronutrient intakes of nonsupplemented pre- and postmenopausal women with a perspective on menopause-associated diseases. J Hum Nutr Diet 17, 121-132.

Massey LK (2003) Dietary animal and plant protein and human bone health: a whole foods approach. $J$ Nutr 133, 862S-865S.

Maurer M, Riesen W, Muser J, Hulter HN \& Krapf R (2003) Neutralisation of Western diet inhibits bone resorption independently of $\mathrm{K}$ intake and reduces cortisol secretion in humans. Am J Physiol Renal Physiol 284, F32-F40.

Melkko J, Kauppila S, Niemi S, Risteli L, Haukipuro K, Jukkola A \& Risteli J (1996) Immunoassay for intact amino-terminal propeptide of human type I procollagen. Clin Chem 42, 947-954.

Moreiras O, Carbajal A, Cabrera L \& Cuadrado C (2001) Tablas de Composición de Alimentos (Food Composition Tables). Madrid: Ediciones Pirámide, SA.

Neville CE, Robson PJ, Murray LJ, Strain JJ, Twisk J, Gallagher AM, McGuinness M, Cran GW, Ralston SH \& Boreham CA (2002) The effect of nutrient intake on bone mineral status in young adults:
The Northern Ireland Young Hearts Projects. Calcif Tissue Int 70, 89-98.

New S (2002) The role of the skeleton in acid-base homeostasis. Proc Nutr Soc 61, 151-164.

Qi L, Shen H \& Ordovas JM (2003) Hearts and bones. Nutr Metab Cardiovasc Dis 13, 165-174.

Schoppen S, Pérez-Granados AM, Sarría B, Navas S, Carbajal A, SanchezMuniz FJ \& Vaquero MP (2003) Influence of an alkaline mineral water on postprandial lipaemia in postmenopausal women. Proc Nutr Soc 62, 43.

Schoppen S, Pérez-Granados AM, Carbajal A, Oubina P, Sanchez-Muniz FJ, Gomez-Gerique JA \& Vaquero MP (2004) A sodium-rich carbonated mineral water reduces cardiovascular risk in postmenopausal women. J Nutr 134, 1058-1063.

Schorr U, Distler A \& Sharma AM (1996) Effect of sodium chloride- and sodium bicarbonate-rich mineral water on blood pressure and metabolic parameters en elderly normotensive individuals: a randomised doubleblind crossover trial. J Hypertens 14, 131-135.

Schroll K, Carbajal A, Decarli B, Martins I, Grunenberger F, Blauw YH \& de Groot CP (1996) Food patterns of elderly Europeans. SENECA Investigators. Eur J Clin Nutr 50, S86-S100.

Sebastian A, Harris ST, Ottaway JH, Todd KM \& Morris RC (1994) Improved mineral balance and skeletal metabolism in postmenopausal women treated with potassium bicarbonate. $N$ Engl J Med 330, $1776-1781$.

Seibel MJ (2000) Molecular markers of bone turnover: biochemical, technical and analytical aspects. Osteoporos Int 11, S18-S29.

Siener R, Jahnen A \& Hesse A (2004) Influence of a mineral water rich in calcium, magnesium and bicarbonate on urine composition and the risk of calcium oxalate crystallization. Eur J Clin Nutr 58, 270-276.

Smit E, Nieto FJ, Crespo CJ \& Mitchell P (1999) Estimates of animal and plant protein intake in US adults: results from the Third National Health and Nutrition Examination Survey, 1988-91. J Am Diet Assoc 99, $813-820$.

Tilney C, Torgerson DJ, Al-Janabi M \& New S (2003) Is salt an important risk factor for osteoporosis? A systematic review of the evidence. Proc Nutr Soc 62, 57A.

Trichopoulou A \& Lagiou P (1997) Healthy traditional Mediterranean diet: an expression of culture, history and lifestyle. Nutr Rev 55, $383-389$.

Tucker KL, Hannan MT, Chen H, Cupples LA, Wilson PW \& Kiel DP (1999) Potassium, magnesium, and fruit and vegetable intakes are associated with greater bone mineral density in elderly men and women. Am J Clin Nutr 69, 727-736.

Van Dokkum W, de la Gueronniere V, Schaafsma G, Bouley C, Luten J \& Latge C (1996) Bioavailability of calcium of fresh cheeses, enteral food and mineral water. A study with stable calcium isotopes in young adult women. Br J Nutr 75, 893-903.

Vaquero MP, Pérez-Granados AM \& Schoppen S (2001) Propiedades fisiológicos y nutricionales de las aguas minerales naturales carbónicas (Physiological and nutritional properties of carbonated natural mineral waters). Rev Nutr Práctica 5, 43-52.

Willett W (1998) Nutritional Epidemiology, 2nd ed, New York: Oxford University Press.

World Health Organization (1994) Assessment of Fracture Risk and Its Application to Screening for Postmenopausal Osteoporosis. Technical Report Series no. 843. Geneva: WHO. 